Antoinette Burton, Empire in Question: Reading, Writing and Teaching British imperialism (Durham and London: Duke University Press, 2011)

[Paper back ISBN: 978-0822349020/RRP: f16.99] [Hardback ISBN: 978-0822348801/RRP: f67.00]

\title{
Transnational dialogues: Antoinette Burton and the rewritings of British imperial history
}

For nearly twenty years Antoinette Burton has practiced and proselytised the 'new imperial history'. Few interested readers will be unaware of Burton's contribution to the field of British studies even if, as many of the essays reproduced here make clear, a fundamental objective of Burton's work has been 'displacing the nation from the centre stage' of historical analysis (55). Already widely anthologised, Burton's writing has helped to shape many of the historiographical debates which continue to animate British and imperial history. By emphasising the transmissions between her reading, writing and teaching of British imperialism, Empire in Question provides a reflective and engaging overview of Burton's insistence that 'Victorian culture... cannot be understood outside the ambit of empire, imperial power and its constitutive impact' (2).

Bookended by two new essays, and by generous contributions from Mrinalini Sinha and C.A. Bayly, Empire in Question ranges from Victorian politics and culture via empire and its effects to the teaching of British history in twenty-first century America. As the part-autobiographical introductory essay 'Imperial Optics' makes clear, Burton's analyses reflect the pedagogic labours of teaching Victorian studies in the North American academy. This 'curricular genealogy' emphasises how profoundly her readings of Victorian empire have been influenced by the interplay of imperial past and postcolonial present: 'the dialectical relationship between imperial history and the imperial and imperializing present' lead Burton to conclude that 'empire history is never disinterested and is only ever partial and provisional' (18-9). Thus, the Bradford riots of 2001, the murder of Stephen Lawrence, and more prosaically, $9 / 11$ and $7 / 7$, both recall the context from which the 'new imperial history' emerged and emphasise 'the stakes of national-imperial history in a postcolonial frame' (13).

Literary studies, anthropology and cultural geography provide as much - perhaps more - of the intellectual scaffolding for Empire in Question as do older historiographical traditions: discursive, performative and spatial analytics abound. Burton thus locates the distinctiveness of Victorian history not in the triumphalism of Whiggish exceptionalism but rather in the encounters and exchanges that shaped British power and produced the 'imperial social formations' which sedimented the nation's sovereign place in historical narrative. 'Who Needs the Nation' upbraids historians - including those emphasising empire's importance to Victorian history - for exaggerating the coherence of bounded national frames and delimiting our ability to understand and interrogate history's complicity in the naturalisation of the nation state. Returning to a related theme in her Coda, 'Getting Outside of the Global', Burton argues that much recent work in 'global history' is similarly flawed, particularly in its uncritical depiction of imperial Britain as progenitor of 'Angloglobalization'. Such readings, Burton argues, risk re-centering Britain and her empire, obscuring the wider tributaries and competing forces which shaped the unstable history of British imperialism. Burton offers a provocative and persuasive argument for histories which 'look beyond the paramountcy of the British model', though the perils of careless comparison are illustrated in her unsubstantiated and highly implausible claim that 'Bismarck's Weltpolitick bespoke a PanGermanism that aimed to rival British imperial aspirations' (282). ${ }^{\text {i }}$

Fortunately, the substantive historical essays cover more familiar ground and here, as in her influential monographs, Burton's analysis is subtle, original and incisive. 'Tongues Untied' reveals 
how Victorian racial hierarchies were worked - and re-worked - across global and domestic referents. Race, Burton shows, was vital to British politics at the same time that politics was central to the elaboration of Victorian taxonomies of race: Lord Salisbury's boorish slur on the 'colour' of an Indian parliamentary candidate and the alternative racial hierarchies deployed by his critics, reveal the 'fundamentally transnational nature of British political culture in the fin de siecle' (219). Dynamic and polyvalent, Burton's reading of the case illustrates the multiple transmissions and encounters which endowed race with contemporary significance. Other essays locate gender in similar analytic fields and it is in the dialogic readings of empire and gender that Burton's contribution to Victorian and imperial - studies is perhaps most apparent. In her analysis of Mary Carpenter's agitations for imperial social reform and of the campaigns to educate 'Lady Doctors for India', Burton shows how the 'plight' of Indian women provided a vehicle for Victorian feminists' claims to public and political agency. Similarly, 'From Child Bride to "Hindoo Lady"' offers a deft reading of the celebrated case of the Rukhmabai, the child bride, demonstrating how discourses of gender, law and politics traversed colonial and metropolitan circuits. As Rukhamabai resisted her betrothal via the Indian courts and the metropolitan media - appealing directly to Victoria on behalf of the 'millions of [her] Indian daughters' (208) doomed to infant marriage - she demonstrated how notions of women's respectability could be produced, and contested, beyond national frames: 'performances of women's virtue were staged neither in Britain nor in India alone but in the transnational communities of colonial culture that imperial social formation generated' (212). Though Burton's prose is sometimes dense, the analysis is sharp and precise skilfully illuminating the dialectic of metropole and colony to reveal Victorian culture and politics as racialised landscapes.

Many of these arguments are now familiar. In collecting the essays together, Empire in Question offers a genealogy of Burton's dialogues with the interlocutors - from Cohn, Said and Spivak to contemporaries like Catherine Hall and Mrinalhi Sinha - whose work has also influenced the genesis of the new imperial history. As a cursory survey of Anglo-American reading lists will confirm, these are the works which now undergird imperial history and historiography. ${ }^{\text {ii }}$ Indeed, if Burton's attack on the 'disciplinarity' of 'empiricist' methodologies feels dated, this is partly because the influence of the cultural turn has been so profound. Burton suggests that her combative and polemical style reflects the 'indifference, contempt and outrage' that met early presentations of her work and, instructively, Empire in Question recalls several significant antagonists: the Oxford History of the British Empire, David Cannadine and Niall Ferguson, amongst others, provide sounding boards against which Burton distinguishes her own readings of empire and, significantly, her own politics (9). Borrowing Stoler's notion of 'precarious vulnerability' to characterise the instability of the British imperial system Burton makes a persuasive case for rejecting 'whitewashed' histories of 'AngloSaxon' imperialism. However, in hanging this critique around Ferguson's Empire - hardly a central text for scholars of the Victorian empire, whatever its Amazon.com sales might suggest - the political imperative threatens to obscure the historiographical one.

As the barbed critique of Ferguson makes clear, Burton's polemical verve derives partly from her insistence on reading empire's past in terms of its political present - an approach also reflected in her pursuit of empire's traces in contemporary media and culture. Though not unproblematic, this approach can be suggestive and provocative: while devolution and the return of Hong Kong have not (yet) proved the disjuncture with the imperial past that Burton anticipated in 2003's 'When Was Britain?', her framing of empire vis-à-vis urban rioting, the murder of Stephen Lawrence and history's place in the national curriculum now seems particularly prescient. At the same time, recent 
events demonstrate how widely the relationship between Britain's imperial past and postcolonial present is being rethought: the widespread incredulity at David Starkey's analysis of recent riots suggests how far 2011 is from 1981 and 1968. ${ }^{\text {iii }}$ Similarly, while traces of imperial nostalgia linger in parts of British culture, more subtle analyses of nation and empire are increasingly prominent. In different ways, the Museum of London's permanent 'London, Sugar and Slavery' gallery, the National Theatre's production of Richard Bean's England People Very Nice, and the Tricycle's Testing the Echo all reflect the dialogues which are the central concern of Burton's work. In contemporary culture, as in the academy, the influence of the postcolonial critique is unmistakable.

Burton's restlessness precludes any triumphalism, as the new essays offered here confirm. Indeed, in lamenting the passing of the 'fugitive character' of earlier feminist and postcolonial critiques, Empire in Question suggests that Burton is more comfortable sniping on the grounds of 'global history' than defending the borders of 'the new imperial history' (22). In fact, Burton is attentive to the limits and oversights of postcolonial history. 'Recapturing Jane Eyre', for example, worries - with good reason - that 'too much of the weight of critical attention has fallen on the literary dimensions of the colonial encounter' (179). Though Burton's readings of Victorian sexual and political respectability provide historical counterweights to the literary focus of much recent cultural history, and illuminate the presence of empire in Victorian culture, law and, high politics, the essays in Empire in Question - like the rest of Burton's work - remain principally discursive in methodology. With the exception of several brief discussions of imperial wars - usually their representations in metropolitan culture - little is said of the military, economic and material bases of Britain's empire, or of the various ways that cultural history might illuminate these and other subjects, including the place of class in cartographies of Victorian race and gender. ${ }^{\text {iv }}$ As a number of recent works have suggested, empire produced 'imperial economic formations' and 'imperial military formations' akin to the 'imperial social formations' skilfully dissected by Burton. ${ }^{\mathrm{V}}$ Critics - of Burton and of the cultural turn more generally - have read this lacuna as a sign of cultural history's 'soft' underbelly, a reading which usually precedes the reassertion of the primacy of one or other of the 'hard' themes purportedly ignored by cultural historians. Though Burton bristles against such 'empiricist' readings of Britain's history, Empire in Question has little to say about the relationship of culture to military and economic power, an absence which confirms the sub-disciplinary division of labour that separates histories of 'representation' from histories of 'reality'. This is the methodological animus which sustains Burton's long-running and ill-tempered dialogue with Bernard Porter, and which also underpins the more temperate but equally robust critique offered by Peter Marshall. ${ }^{\mathrm{vi}}$ Ironically, then, even whilst it registers the impacts of the linguistic, cultural and imperial turns, some readers may find Empire in Question also confirms the limits of such approaches.

Though Empire in Question enters a competitive market, Burton's influence will doubtless - and justifiably - secure a readership. Recording the emergence of the 'imperial turn' through Burton's seminal essays, Empire in Question provides a partial but nonetheless revealing genealogy of the 'new imperial history'. Though Burton's style, aphorisms and interests are unlikely to find universal favour, Empire in Question deserves to be read and discussed, especially for the reflective and contextual account it provides for Burton's argumentative, challenging and important interventions in the field. Many questions, of course, remain to be asked but Antoinette Burton's interrogation of empire has made reading, writing and teaching British imperialism a more stimulating and rewarding enterprise. 


\section{Notes on Contributors}

Gavin Rand teaches history at the University of Greenwich. He has published on race, empire and imperial governance and is currently working on a cultural history of the Indian Army in the nineteenth and twentieth centuries.

\footnotetext{
'Ironically, given Burton's arguments about Anglo-centrism, Bismarck's vision was decidedly less Anglo-centric than advocates of German imperial expansion like Peters and Fabri, whose positions were much more closely aligned to the Pan-Germans. See Chickering, Roger. We Men Who Feel Most German: A Cultural Study of the Pan-German League, 1886-1914 (Boston, Mass. and London: Allen and Unwin, 1984)

ii Burton's collaboration with Jean Allman on the 'Gender and Colonialism' course at the University of Illinois, outlined and introduced in Chapter Seven, is exemplary though, as Burton's summary of the course correctly notes, its comparative approach is, sadly, more unusual (110).

iii ‘David Starkey's Newsnight race remarks', Guardian. 15 August 2011.

http://www.guardian.co.uk/media/2011/aug/15/david-starkey-newsinght-race-remarks;

'Starkey's ignorance is hardly work of history', THE. 25 August 2011.

http://www.timeshighereducation.co.uk/story.asp?storycode $=417236$

${ }^{\text {iv }}$ A point gently, but usefully, made in Bayly's thoughtful 'Afterword' (298).

' See, for example, Goswami, Manu. Producing India: From Colonial Economy to National Space. (Chicago: University of Chicago Press, 2004), cited by Burton and Green, Nile. Islam and the Army in Colonial India: Sepoy Religion in the Service of Empire. (Cambridge: Cambridge University Press 2009)

${ }^{v i}$ See, for example, Burton's 'Review. Bernard Porter, The Absent Minded Imperialists: Empire, Society and

Culture in Britain'. Victorian Studies 47, no 4 (2005) 626-8 and Porter's response 'Further Thoughts on Imperial Absent-Mindedness' The Journal of Imperial and Commonwealth History 36, 1 (2008), 101-117. P.J. Marshall's initial appraisal was in his 'No Fatal Impact: The Elusive History of Imperial Britain' Times Literary Supplement, 12 March 1993, 8-10; see also Marshall, Peter J. 'Foreword: British Imperial History 'New' and 'Old”', History in Focus: Empire. http://www.history.ac.uk/ihr/Focus/Empire/index.html.
} 